УДК 328.3: 327(477+327.7НАТО)

Я. О. Бень, аспірант кафедри глобалістики, євроінтеграчї та управління начіональною безпекою, Начіональна академія державного управління при Президентові України

ORCID ID: 0000-0002-4222-813X

DOI: $10.32702 / 2306-6814.2021 .10 .153$

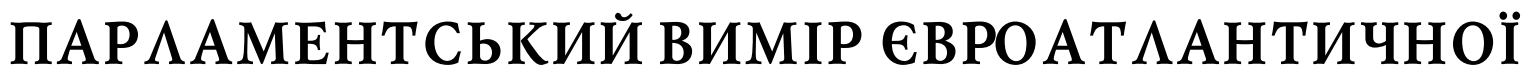 ІНТЕГРАЦІї УКРАЇНИ
}

\author{
Ya. Ben, \\ Postgraduate student of the Department of Globalistics, European Integration and National Security, \\ National Academy for Public Administration under the President of Ukraine
}

\section{PARLIAMENTARY DIMENSION EURO-ATLANTIC INTEGRATION OF UKRAINE}

\begin{abstract}
Устатті досліджено діяльність Верховної Ради України з питань євроатлантичної інтеграції держави. Доведено, що на особливостієвроатлантичної політики України безпосередньо впливає форма державного правління. Серед форм державного правління періоду політичної незалежності України статистично (у вимірі років) домінує форма президентсько-парламентської республіки, хоча з 2014 р. вітчизняна політична система повернулась до парламентсько-президентської форми республіканізму. Проте за будь-яких організаційних форм державного правління національний парламент був і залишається важливим суб'єктом вироблення та втілення в життя євроатлантичної політики України, метою якоїє набуття
\end{abstract} членства в Організації Північноатлантичногодоговору.

Парламентськими напрацюваннямиз питань євроатлантичної інтеграції послідовно стали: Постанова Верховної Ради України від 21.11.2002 р. "Про рекомендації парламентських слухань про взаємовідносини та співробітництво України з НАТО"; Закон України від 19.06.2003 р. "Про основи національної безпеки України"; Закон України "Про національну безпеку України" від 21.06.2018 р.; Конституція (Основний Закон) України зі змінами від 07.02.2019 р.; Закон України від 03.12.2019 р. "Про Заяву Верховної Ради України щодо першочергових кроків забезпечення євроатлантичної інтеграції України - набуття повноправного членства України в Організації Північноатлантичного договору". У Заяві наголошено, що сьогодні Україна фактично є східним кордоном НАТО і своєю самовідданістю у відсічі російської агресії робить значний внесоку гарантування миру ібезпеки на всьомутрансатлантичномупросторі. Виходячи 3 цього, підтримка інтеграції України в Організацію Північноатлантичного договорує найбільш ефективною інвестицією у забезпечення миру і безпеки, черговим кроком до зміцнення системи міжнародної безпеки.

На основі згаданих вище документів сформовано механізм парламентського співробітництва України з НАТО. Його елементами (складовими частинами) є: законодавче забезпечення питань, пов'язаних 3 відносинами між Україною та НАТО; співпраця Верховної Ради України з Парламентською асамблеєю НАТО (у Парламентській асамблеї НАТО Україназ 1992 р. представлена Постійноюделегацією Верховної Ради); парламентський контроль за реалізацією законодавчих рішень щодо інтеграції України в євроатлантичний безпековий простір, досягнення критеріїв, необхідних для набуття членства в НАТО.

Недоліком узабезпеченнієвроатлантичного курсу України, яка послаблює ефективність вказаного механізму, є відсутність в українському парламенті профільного комітету з питань євроатлантичної інтеграціі.

Попри наявність механізму парламентського співробітництва України з НАТО приблизна дата вступу України до Альянсу не визначена. Це означає необхідність активізації діяльності законодавчого органу України з питань євроатлантичної інтеграції.

The article examines the activities of the Verkhovna Rada of Ukraine on Euro-Atlantic integration of the state. It is proved that the peculiarities of Ukraine's Euro-Atlantic policy are directly influenced by the form of government. Among the forms of government of the period of political independence of Ukraine, the form of the presidential-parliamentary republic dominates statistically (in terms of years), although since 2014 the domestic political system has returned to the parliamentary-presidential form of republicanism. However, under any 
organizational form of government, the national parliament has been and remains an important subject in the development and implementation of Ukraine's Euro-Atlantic policy, which aims to become a member of the North Atlantic Treaty Organization.

Euro-Atlantic parliamentary achievements have consistently been: Resolution of the Verkhovna Rada of Ukraine of 21 November 2002 "On Recommendations of Parliamentary Hearings on Relations and Cooperation between Ukraine and NATO"; Law of Ukraine of June 19, 2003 "On the Fundamentals of National Security of Ukraine"; Lawof Ukraine "On National Security of Ukraine" of June 21, 2018; Constitution (Basic Law) of Ukraine as amended on February 7, 2019; Law of Ukraine of December 3, 2019 "On the Statement of the Verkhovna Rada of Ukraine on Priority Steps to Ensure Ukraine's Euro-Atlantic Integration - Acquisition of Full Membership of Ukraine in the North Atlantic Treaty Organization". The statement stressed that today Ukraine is in fact NATO's eastern border and that its commitment to repelling Russian aggression makes a significant contribution to ensuring peace and security throughout the transatlantic space. Based on this, supporting Ukraine's integration into the North Atlantic Treaty Organization is the most effective investment in peace and security, another step towards strengthening the international security system.

Based on the above-mentioned documents, a mechanism of parliamentary cooperation between Ukraine and NATO has been formed. Its elements (components) are: legislative support for issues related to relations between Ukraine and NATO; cooperation of the Verkhovna Rada of Ukraine with the NATO Parliamentary Assembly (Ukraine has been represented in the NATO Parliamentary Assembly since 1992 by the Permanent Delegation of the Verkhovna Rada); parliamentary control over the implementation of legislative decisions on Ukraine's integration into the Euro-Atlantic security space, achievement of the criteria necessary for NATO membership.

A shortcoming in ensuring Ukraine's Euro-Atlantic course, which weakens the effectiveness ofthis mechanism, is the lack of a profile committee on Euro-Atlantic integration in the Ukrainian parliament.

Despite the existence of a mechanism for parliamentary cooperation between Ukraine and NATO, the approximate date of Ukraine's accession to the Alliance has not been determined. This means the need to intensify the activities of the Ukrainian parliament on Euro-Atlantic integration.

КлючоВіслоВа: президентсько-парламентська республіка, парламентсько-президентськареспубліка, НАТО, Альянс, єВроатлантична інтеграція, діяльність з питаньєВроатлантичної інтеграції, механізм парламентського спіВробітниитВа України з НАТО.

Key words: presidential-parliamentary republic, parliamentary-presidential republic, NATO, Alliance, Euro-Atlantic integration, activities on Euro-Atlantic integration, the mechanism of parliamentary cooperation between Ukraine and NATO.

\section{ПОСТАНОВКА ПРОБ $А$ МИ У \\ ЗАГААЬНОМУ ВИГ АЯАІ}

Суб'єктами євроатлантичної інтеграції України є всі конституційно визначені гілки влади - законодавча, виконавча, судова. Серед них особлива роль належить законодавчій владі (Верховній Раді України), оскільки парламентські рішення з питань вироблення та втілення в життя державної євроатлантичної політики були й залишаються визначальними у державотворчому процесі. Попри неодноразові зміни форми державного правління в Україні (президентська республіка, президентсько-парламентська республіка, парламентсько-президентська республіка) саме Верховна Рада здійснює конституційне (законодавче) забезпечення євроатлантичного курсу України. До історично важливих парламентських напрацювань з питань євроатлантичного вибору слід віднести конституційне закріплення "незворотності європейського та євроатлантичного курсу України", законодавче віднесення євроатлантичної мети спочатку до "пріоритетів національних інтересів", пізніше - до "фрудаментальних національних інтересів", законодавчо закріплене нагадування західній та світовій спільнотам, що Україна вже зараз "фрактично є східним кордоном HATO", демонструючи "самовідданість у відсічі рос- ійської агресії" та роблячи "значний внесок у гарантування миру й безпеки на трансатлантичному просторі". Постійно використовується механізм парламентського співробітництва України з НАТО, започаткований у 1992 р.

Водночас рівень парламентської активності щодо досягнення кінцевої мети - вступу України до Організації Північноатлантичного договору в якості постійного члена - слід визнати недостатнім. Зокрема, у законодавчому органі України залишається відсутнім парламентський комітет (підкомітет) з питань євроатлантичної інтеграції. Недостатньою задля досягнення кінцевої мети виглядає парламентська взаємодія з державами, що є "критично важливими" для отримання Україною Плану дій щодо членства (ПДЧ) та наступного вступу до Альянсу - ФРН, Францією, Італією, Угорщиною та ін. Більш дієвим з боку парламенту могло б бути внутрішньополітичне стимулювання діяльності легітимних органів влади, політичних партій, суспільно-політичних рухів, громадських організацій, мас-медійних структур щодо прискорення євроатлантичного руху Української держави. Відповідно, тема парламентської складової євроатлантичної інтеграції України виглядає актуальною та змістовно цікавою у теоретичному та практичному аспектах. 


\section{АНА $\Lambda$ I3 ОСТАНHIX АОС $\Lambda$ IАЖЕНЬ

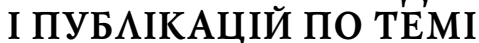

Державно-політичні та правові проблеми євроатлантичної інтеграції України розглянуто у працях В. Бакуменка, О. Деменка, К. Коцюруби, І. Кресіної, А. Кудряченка, С. Ліпкевича, Я. Малика, Б. Парахонського, В. Пашинського, Г. Перепелиці, С. Пирожкова, О. Пошедіна, О. Прилипчука, В. Рєзнікова, О. Скрипнюка, О. Стойко, І. Тодорова, М. Фесенка, Л. Чекаленка, М. Юрчак, В. Явір, А. Яковлєва та інших дослідників. Національна науково-інформаційна сфера дедалі більше насичується різноманітними роботами щодо суб'єкт-суб'єктної та суб'єкт-об'єктної структуризації євроатлантичної політики України з конкретизацією суспільно-політичних, воєнно-стратегічних, військово-технічних, інформаційних, освітніх та інших ефектів, які виникають під час взаємодії Києва і Брюсселя. Проте роль законодавчого органу (Верховної Ради України) у контексті євроатлантичного руху держави у більшості праць розглядається досить фрагментарно. Виходячи з цього, доцільно більш детально висвітлити роль національного парламенту на шляху поглиблення процесу євроатлантичної інтеграції України.

\section{ЦІАІ СТАТТІ}

Аргументувати особливу роль Верховної Ради України за різних фрорм державного правління (президентської, президентсько-парламентської, парламентсько-президентської республіки) з питань визначення засад внутрішньої і зовнішньої політики, зокрема питань євроатлантичної інтеграції. Вказати на законодавчий доробок українського парламенту (внесення змін до Конституції України, розробку законодавства з питань євроатлантичної інтеграції), де зафріксована стратегічна мета державного розвитку - набуття повноцінного членства в Організації Північноатлантичного договору. Вказати на наявність механізму парламентського співробітництва України з НАТО та його складові. Конкретизувати недоліки діяльності законодавчого органу України $з$ питань євроатлантичної інтеграції держави.

\section{ВИК ААА ОСНОВНОГО МАТЕРІААУ АОС $\triangle$ IАЖЕНHЯ}

Верховна Рада України була й залишається одним 3 основних суб'єктів розробки та практичної реалізації євроатлантичної політики України. Насампередце пояснюється фрормою державного правління в Україні, яка упродовж періоду державно-політичної незалежності коливалася між парламентсько-президентським та президентськопарламентським різновидами з незначним перебуванням у форматі президентської республіки (1995-1996рр.). Якщо взяти за точку відліку 1996 р. (прийняття Конституції України), то, як зазначає В.Червоненко, "десять років Україна прожила в президентсько-парламентській республіці, потім, з 2006 по 2010, - у парламентсько-президентській, а після цього - знову відбулося чотирирічне повернення до президентської моделі" [1].

Більш детально зміни довкола фрорми державного правління пояснює П. Мироненко: "За період своєї незалежності Україна трансформувалася з де-сракто президентської республіки (за наслідками конституційної угоди 1995 р. Президент визнавався головою виконав- чої влади) через етап президентсько-парламентської республіки у 1996-2006 рр. до парламентсько-президентської у 2006-2010рр. Скасування конституційної реформи у 2010 р. повернуло Україну до президентсько-парламентської форми правління, хоча в умовах фактичної маргіналізації парламенту та уряду відбувався наростаючий процес "президентціалізації" влади. Такий стан справ, зрештою, зумовив узурпацію всієї владної вертикалі й горизонталі та спровокував революційну ситуацію кінця 2013 - початку 2014 р." [2, с. 142]. Одним з результатів Революції Гідності 2013-2014рр., значення якої не підлягає сумніву, стало повернення України до парламентсько-президентської форми правління, яка, маючи внутрішні структурно-функціональні коливання, продовжується в сучасних умовах.

Таким чином, можемо навести наступну статистику стосовно співвідношення у вітчизняних державотворчих реаліях президентсько-парламентської та парламентсько-президентської форми державного правління.

1991-1995 рр. - період невизначеності форми республіканізму в умовах формального існування Конституції УРСР з численними поправками;

1995-1996 рр. (від прийняття Конституційного Договору між Верховною Радою України та Президентом України про основні засади організації та функціонування державної влади і місцевого самоврядування від 08.06.1995 р. до прийняття Конституції України 28.06.1996 р.) - президентська республіка;

1996-2006 рр. - президентсько-парламентська республіка;

2006-2010 рр. - парламентсько-президентська республіка;

2010-2014 рр. - президентсько-парламентська республіка;

після 2014 р. - парламентсько-президентська республіка.

Як видно, протягом періоду державності (станом на 2021 р.) Україна 1 рік була президентською республікою (без нормативно-правового закріпленняцього факту), 11 років - парламентсько-президентською та 14 років - президентсько-парламентською, що яскраво засвідчує суперечливий характер національного державотворення. Одночасно це переконливо демонструє затягування в часі процесу оптимізації форми державного правління, наслідком чого стала нестабільність політичної системи та, як наслідок, уповільнення темпів назрілих перетворень внутрішньо- та зовнішньополітичного гатунку.

Позиція Конституційного Суду України щодо визначення форми державного правління $€$ наступною: "Із системного аналізу норм Конституції України, зокрема ії статей $5,83,85,87,102,103,106,107,113,114,115$, вбачається, що Україна є республікою зі змішаною формою державного правління. Це стосується специфрічності фрормування уряду парламентом та главою держави, а також його відповідальності перед Президентом України та підконтрольності і підзвітності Верховній Раді України" [3].

Попри суперечливі процеси розподілу (перерозподілу) повноважень між Президентом України та Верховною Радою України остання завжди відігравала надзвичайно важливу роль у прийнятті рішень зовнішньополітичного гатунку, в тому числі тих, що стосувалися євроатлантичного курсу держави та питань забезпечення на- 
ціональної обороноздатності [4]. Це повністю корелюється з повноваженнями Верховної Ради, визначеними ст. 85 Конституції України (п. 5: "визначення засад внутрішньої і зовнішньої політики"; п. 32: "надання законом згоди на обов'язковість міжнародних договорів України").

Першим нормативним документом у сорері співробітництва України з НАТО стала Постанова Верховної Ради України від 21.11.2002 р. "Про рекомендації парламентських слухань про взаємовідносини та співробітництво України з НАТО" [5]. У цьому документі український парламент вперше висловив свою підтримку курсу на набуття Україною повноправного членства в Організації Північноатлантичного договору. Учасники парламентських слухань відзначили, що євроатлантична інтеграція України є суттєвим фрактором зміцнення ії національної безпеки, покликаним сприяти розвитку демократичних інститутів, громадянського суспільства, захисту прав і свобод людини, відповідає життєво важливим інтересам Українського народу.

Метою євроатлантичної інтеграції України було названо гарантування її незалежності, територіальної цілісності, суспільного прогресу, запобігання виникнен-

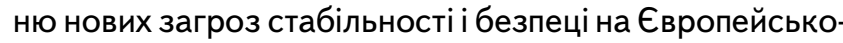
му континенті. Одним із визначальних чинників успішного просування України цим курсом названо "інтенсиорікацію процесу підготовки України до членства в НАТО відповідно до рішення Ради національної безпеки і оборони України від 23 травня 2002 року "Про Стратегію України щодо Організації Північноатлантичного договору (НАТО)" та відповідного Указу Президента України від 8 липня 2002 року".

До наступних нормативно-правових актів з питань євроатлантичної інтеграції, прийнятих українським парламентом, слід віднести наступні.

Закон України від 19.06.2003 р. "Про основи національної безпеки України" до пріоритетів національних інтересів України відніс "інтеграцію України в європейський політичний, економічний, правовий простір з метою набуття членства в Європейському Союзі та в євроатлантичний безпековий простір з метою набуття членства в Організації Північноатлантичного договору" [6].

Протилежний вектор руху в напрямі "від НАТО" продемонстрував Закон України від 01.07.2010 р. "Про засади внутрішньої і зовнішньої політики України". Документ визначив позаблоковий статус Української держави, що робило неможливим продовження її євроатлантичної інтеграції. На основі цього Закону були внесені відповідні поправки до чинного законодавства (зокрема, із Закону України від 19.06.2003 р. "Про основи національної безпеки України" була вилучена мета щодо набуття членства в Організації Північноатлантичного договору) [7].

23.12.2014 р. Верховна Рада України за поданням Президента України П. Порошенка ухвалила Закон України "Про внесення змін до деяких законів України щодо відмови України від здійснення політики позаблоковості" [8]. Відповідно до цього Закону, у ст. 6 Закону України "Про основи національної безпеки України" від 10.06.2003 р. було відновлено положення, що серед пріоритетів національних інтересів $€$ інтеграція України у європейський політичний, економічний, правовий простір з метою набуття членства в Європейському Союзі та в євроатлантичний безпековий простір.
Закон України "Про національну безпеку України" від 21.06.2018 р. посилив нормативно-правову фріксацію євроатлантичного курсу держави. Зокрема, фундаментальним національним інтересом України було визначено "інтеграцію України в європейський політичний, економічний, безпековий, правовий простір, набуття членства в Європейському Союзі та в Організації Північноатлантичного договору".

Чіткість формулювання наміру щодо євроатлантичної інтеграції України посилилась за рахунок віднесення євроатлантичного вектору до "фундаментальних національних інтересів" у Законі України від 21.06.2018 р. "Про національну безпеку України" [9].

07.02.2019 р. положення про євроатлантичний курс України вперше в умовах її незалежного державно-політичного розвитку були внесені в Основний Закон [10]. Цим же Законом з Конституції України було виключено пункт 14 розділу XV "Перехідні положення", який передбачав використання існуючих військових баз на території України для тимчасового перебування іноземних військових формувань на умовах оренди відповідно до міжнародних договорів.

Документ підтримали депутати з фракцій БПП (Блок Петра Порошенка), "Народний фрронт", "Самопоміч", "Батьківщина"та "Радикальна партія", а також більшість позафракційних та група "Воля народу" (всього 334 голоси). Проти висловилась фрракція "Опозиційний блок".

Сукупність внесених змін до Основного Закону звучить так [11]: у Преамбулі Конституції України зазначається: "Верховна Рада України, ... підтверджуючи європейську ідентичність Українського народу і незворотність європейського та євроатлантичного курсу України... приймає цю Конституцію - Основний Закон України";

у розділі IV "Верховна Рада України" до парламентських повноважень віднесено (ст. 85): "визначення засад внутрішньої і зовнішньої політики, реалізація стратегічного курсу держави та набуття повноправного членства України в Європейському Союзі та в Організації Північноатлантичного договору";

у розділі V "Президент України" вказується (ст. 102): "Президент України є гарантом реалізації стратегічного курсу держави на набуття повноправного членства України в Європейському Союзі та в Організації Північноатлантичного договору";

у розділі VI "Кабінет Міністрів України. Інші органи виконавчої влади" вказується (ст. 116): уряд "забезпечує реалізацію стратегічного курсу держави на набуття повноправного членства України в Європейському Союзі та Організації Північноатлантичного договору".

Конституційне закріплення мети щодо набуття Україною членства в НАТО має надзвичайно вагоме державотворче та суспільно-політичне значення [12]. Насамперед, Конституція України як Основний Закон держави за своєю юридичною природою $є$ актом установчої влади, що належить народу. Установча влада по відношенню до так званих встановлених влад - законодавчої, виконавчої, судової - $є$ первинною.

Закони є актами встановленої Конституцією України законодавчої влади. Більше того, вони є актами єдиного органу законодавчої влади - Верховної Ради України. Це зумовлює їх субординацію відносно Конституції України. 
Верховенство конституційних норм поширюється на всі сорери державної діяльності, в тому числі і на законотворчий процес. Верховна Рада України, приймаючи закони, не має права допускати невідповідностей щодо будьяких положень, прямо закріплених в Конституції України.

Пряма дія норм Конституції України означає, що ці норми застосовуються безпосередньо. Законами України та іншими нормативно-правовими актами можна лише розвивати конституційні норми, а не змінювати їх зміст.

Отже, починаючи з конституційних змін 2019 р., євроатлантичний курс України набув вищого правового статусу, що визначає (визначатиме в майбутньому) спрямованість дій усіх державних органів з питань вступу України до НАТО. Відмова від цього курсу можлива лише через внесення відповідних поправок до Конституції. Проте подібні наміри (відмовитись від євроатлантичного курсу, відновити позаблоковість, вступити до воєнно-політичного блоку, контрольованого РФ) звучать лише від поодиноких (маргінальних) політичних сил, нездатних змінити ситуацію, яка склалася.

Парламентська увага до продовження євроатлантичного курсу України була продовжена Законом України від 03.12.2019 р. "Про Заяву Верховної Ради України щодо першочергових кроків забезпечення євроатлантичної інтеграції України - набуття повноправного членства України в Організації Північноатлантичного договору" [13]. У своїй Заяві Верховна Рада України нагадала, що сьогодні Україна фактично $€$ східним кордоном НАТО і своєю самовідданістю у відсічі російської агресії робить значний внесок у гарантування миру і безпеки на всьому трансатлантичному просторі. Український парламент заявив, що підтримка інтеграції України в НАТО і надання нашій державі Плану дій щодо членства в Альянсі (ПДЧ) є найбільш ефективною та вивіреною інвестицією у забезпечення миру і безпеки, черговим кроком до зміцнення системи міжнародної безпеки. Виходячи з цього, законодавчий орган України закликав парламенти держав-членів НАТО на виконання пункту 23 Декларації Бухарестського саміту НАТО 2008 р. звернутися до міністрів закордонних справ своїх держав з пропозицією прискорити надання Україні ПДЧ.

На основі цих та інших документів склався механізм парламентського співробітництва України з НАТО [14]. Його складовими є:

1) законодавче забезпечення питань, пов'язаних 3 відносинами між Україною та НАТО (розглянуте вище);

2) співпраця Верховної Ради України з Парламентською асамблеєю НАТО (у Парламентській асамблеї НАТО Україна представлена Постійною делегацією Верховної Ради, яка з травня 1992 р. має статус асоційованого члена). У Хартії про особливе партнерство між Україною та НАТО від 1997 р. міститься заклик до розширення діалогу та співпраці між Парламентською асамблеєю та Верховною Радою України;

3) парламентський контроль за реалізацією законодавчих рішень щодо інтеграції України в євроатлантичний безпековий простір, досягнення критеріїв, необхідних для набуття членства в НАТО.

Водночас у жодному з розглянутих документів не йдеться про часову конкретику щодо прийняття Украї- ни в НАТО. Як українські зацікавлені структури (насамперед конституційні органи), так й офріційні представники НАТО не називають орієнтовного часу (року), коли прагнення України щодо повноцінного членства в Альянсі, артикульовані у численних документах, стануть реальністю.

Іншим недоліком у забезпеченні євроатлантичного курсу України є відсутність у Верховній Раді України профільного комітету (підкомітету) з питань євроатлантичної інтеграції. Частково цими питаннями займаються комітети з питань інтеграції України до ЄС та з питань національної безпеки, оборони та розвідки. Проте цього замало для забезпечення ефективності парламентського впливу на євроатлантичне просування України, яке за підсумками 2002-2021рр. не вирізняється високою динамікою.

\section{ВИСНОВКИ ТА ПЕРСПЕКТИВИ ПОАААЬШИХ РОЗВІАОК}

Протягом періоду державно-політичної незалежності форма державного правління в Україні неодноразово змінювалась, почергово набуваючи президентського, президентсько-парламентського та парламентсько-президентського вигляду. За визначенням Конституційного Суду України вона є змішаною. Це означає іманентну присутність законодавчого органу України у виробленні стратегічних державних рішень, у тому числі з питань євроатлантичної спрямованості попри ситуаційні коливання форми державного правління.

Верховна Рада України у листопаді 2002 р. заявила про необхідність євроатлантичної інтеграції України $з$ метою набуття повноправного членства в Організації Північноатлантичного договору, підтримавши аналогічні рішення Ради національної безпеки і оборони України від 23.05.2002 р. та Указу Президента України від 08.07.2002 p.

Загальнодержавний курс на вступ до НАТО було повторено й деталізовано в Законах України "Про основи національної безпеки України" від 19.06.2003 р., "Про національну безпеку України" від 21.06.2018р., "Про внесення змін до Конституції України (щодо стратегічного курсу держави на набуття повноправного членства України в Європейському Союзі та в Організації Північноатлантичного договору)" від 07.02.2019р., "Про Заяву Верховної Ради України щодо першочергових кроків забезпечення євроатлантичної інтеграції України - набуття повноправного членства України в Організації Північноатлантичного договору" від 03.12.2019 р.

На основі вказаних вище Законів України, а також інших нормативно-правових актів склався механізм парламентського співробітництва України з НАТО, складниками якого $є$ законодавче забезпечення питань, пов'язаних з відносинами між Україною та НАТО, співпраця Верховної Ради України Парламентською асамблеєю НАТО, а також парламентський контроль за реалізацією законодавчих рішень щодо інтеграції України в євроатлантичний безпековий простір, досягнення критеріїв, необхідних для набуття членства в НАТО.

Вбачається за доцільне більш докладно розглянути механізм парламентського співробітництва України з Організацією Північноатлантичного договору в окремій статті. 
Література:

1. Червоненко В. 19 років поневірянь Конституції. URL: https://www.bbc.com/ukrainian/politics/2015/ 06/150626_constitution_ukraine_history_vc

2. Мироненко П.В. Форма правління: політичні трансформації на зламі століть: монографрія / П.В. Мироненко. К.: ВЦ "Академія", 2014. 220 с.

3. Висновок Конституційного Суду України (Велика палата) у справі за конституційним зверненням Верховної Ради України про надання висновку щодо відповідності законопроекту про внесення змін до статті $106 \mathrm{KoH}-$ ституції України вимогам статей 157 і 158 Конституції України від 16 грудня 2019 року № 7-в/2019. URL: https:/ /ccu.gov.ua/storinka-knygy/29-konstytuciyne-pravo

4. Пашинський В.Й. Верховна Рада України в системі суб'єктів забезпечення оборони держави. URL: file:///C:/Users/ADmin/Downloads / 152698-96330057-1-10-20181225.pdf

5. Про Рекомендації парламентських слухань про взаємовідносини та співробітництво України з НАТО. Постанова Верховної Ради України від 21.11.2002 p. URL: https://zakon.rada.gov.ua/laws/show/233-IV\#Text

6. Про основи національної безпеки України. Закон України від 19.06.2003 р. / URL: https://zakon.rada.gov.ua/laws/show/964-15\#Text

7. Про засади внутрішньої і зовнішньої політики України. Закон України від 01.07.2010 р. (із змінами). URL: https://zakon.rada.gov.ua/laws/show/2411-17\#Text

8. Рада скасувала позаблоковий статус України. URL: https://www.unian.ua / politics / 1025042-radaskasuvala-pozablokoviy-status-ukrajini.html

9. Про національну безпеку України. Закон України від 21.06.2018 р. / URL: https:/ / zakon.rada.gov.ua/ laws/show/2469-19\#Text

10. Про внесення змін до Конституції України (щодо стратегічного курсу держави на набуття повноправного членства України в Європейському Союзі та в Організації Північноатлантичного договору). Закон України від 07.02.2019 р. URL: https://www.rada.gov.ua/news / Novyny/167509.html

11. Конституція України від 28.06.1996р. (із змінами). URL: https://zakon.rada.gov.ua/laws/show/ 254\#Text

12. Конституційний Суд України. Офіційний вебсайт. 2.9. Конституційне право. URL: https://ccu.gov.ua/ storinka-knygy/29-konstytuciyne-pravo

13. Про Заяву Верховної Ради України щодо першочергових кроків забезпечення євроатлантичної інтеграції України - набуття повноправного членства України в Організації Північноатлантичного договору. Закон України від 03.12.2019 p. URL: https://zakon.rada.gov.ua/laws/show/327-IX\#Text

14. Парламентський вимір співробітництва України з HATO. URL: https://ukraine-nato.mfa.gov.ua/ ukrayina-nato/parlamentskij-vimir-spivrobit-nictvaukrayini-z-nato

\section{References:}

1. Chervonenko, V. (2015), "19 years of wandering the Constitution", available at: https://www.bbc.com/ ukrainian / politics/2015/06/150626_constitution_ukraine_history_vc(Accessed 10 May 20̄21).
2. Myronenko, P.V. (2014), Forma pravlinnia: politychni transformatsii na zlami stolit' [Form of government: political transformations at the turn of the century], VTs "Akademiia", Kyiv, Ukraine.

3. Constitutional Court of Ukraine (2019), "Opinion of the Constitutional Court of Ukraine (Grand Chamber) in the case on the constitutional appeal of the Verkhovna Rada of Ukraine on providing an opinion on the compliance of the draft law on amendments to Article 106 of the Constitution of Ukraine with the requirements of Articles 157 and 158 of the Constitution of Ukraine", availableat: https:/ /ccu.gov.ua/storinka-knygy/ 29-konstytuciyne-pravo (Accessed 10 May 2021).

4. Pashyns'kyj, V.J. (2017), "The Verkhovna Rada of Ukraine in the system of subjects of state defense", available at: https://ela.kpi.ua/handle/123456789/25235 (Accessed 10 May 2021).

5. Verkhovna Rada of Ukraine (2002), Resolution "On the Recommendations of the Parliamentary Hearings on Ukraine's Relations and Cooperation with NATO", available at: https://zakon.rada.gov.ua/laws/show/233IV\#Text (Accessed 10 May 2021).

6. The Verkhovna Rada of Ukraine (2003), The Law of Ukraine "On the foundations of national security of Ukraine", available at: https:/ / zakon.rada.gov.ua/laws / show/964-15\#Text (Accessed 10 May 2021).

7. The Verkhovna Rada of Ukraine (2010), The Law of Ukraine "On the principles of domestic and foreign policy", available at: https://zakon.rada.gov.ua/laws/show/ 2411-17 \#Text (Accessed 10 May 2021).

8. Unian (2014), "The Council revoked Ukraine's nonaligned status", available at: https://www.unian.ua/ politics / 1025042-rada-skasuvala-pozablokoviy-statusukrajini.html (Accessed 10 May 2021).

9. The Verkhovna Rada of Ukraine (2018), The Law of Ukraine "On the national security of Ukraine", available at: https://zakon.rada.gov.ua/laws/show/246919\#Text (Accessed 10 May 2021).

10. Verkhovna Rada of Ukraine (2019), The Law of Ukraine "On Amendments to the Constitution of Ukraine (Regarding the Strategic Course of the State on Acquiring Full-fledged Membership of Ukraine in the European Union and the North Atlantic Treaty Organization)", available at: https://www.rada.gov.ua/news/Novyny/167509.html (Accessed 10 May 2021).

11. The Verkhovna Rada of Ukraine (1996), "Constitution of Ukraine", available at: https:/ / zakon.rada.gov.ua/laws / show $/ 254 \%$ D0\%BA/96-Text (Accessed 10 May 2021).

12. Constitutional Court of Ukraine (2021), "Constitutional law", available at: https: / /ccu.gov.ua/storinkaknygy/29-konstytuciyne-pravo (Accessed 10 May 2021).

13. Verkhovna Rada of Ukraine (2019), The Law of Ukraine "On the Statement of the Verkhovna Rada of Ukraine on Priority Steps for Ensuring Ukraine's Euro-Atlantic Integration Acquisition of Full Membership of Ukraine in the North Atlantic TreatyOrganization", available at:https://zakon.rada.gov.ua/ laws/show/327-IX\#Text (Accessed 10 May 2021).

14. Ministry of Foreign Affairs of Ukraine (2021), "Parliamentary dimension of Ukraine's cooperation with NATO", available at: https://ukraine-nato.mfa.gov.ua/ ukrayina-nato / parlamentskij-vimir-spivrobit-nictvaukrayini-z-nato (Accessed 10 May 2021).

Стаття надійшла до редакиї 19.05.2021 p. 